\title{
CSAE WPS/2008-04
}

\author{
Towards an Objective Account of Nutrition and Health in \\ Colonial Kenya: A Study of Stature in African Army \\ Recruits and Civilians, 1880-1980
}

\author{
Alexander Moradi \\ Centre for the Study of African Economies, \\ Nuffield College, Department of Economics \\ University of Oxford \\ Manor Road Building, Oxford OX1 3UQ, UK \\ E-mail: alexander.moradi@economics.ox.ac.uk
}

Keywords: nutrition, health, anthropometrics, inequality, colonial, Kenya JEL: I31, I32, N37

\begin{abstract}
How well did Kenyans do under colonial rule? It is common sense that Kenyans suffered under exploitative colonial policies. The overall impact, however, is uncertain. This study presents fresh evidence on nutrition and health in colonial Kenya by (1) using a new and comprehensive data set of African army recruits and civilians and (2) applying a powerful measure of nutritional status: mean population height. Findings demonstrate huge regional inequalities but only minor changes in the mean height of cohorts born 20 years before and after colonisation. From 1920 onwards secular improvements took place which continued after Independence. It can be concluded that however bad colonial policies and devastating short term crises were, the net outcome of colonial times was a significant progress in nutrition and health.
\end{abstract}

Acknowledgments

I am grateful to the Kenyan Armed Forces, Defence Headquarters, Ulinzi House, Nairobi, Chief of General Staff for granting me access to records of the King's African Rifles. I thank Peterson Kithuka, Maureen Were and Jacinta Sikali for excellent research assistance in Nairobi. I am also grateful to Abigail Barr, Francesco Cinnirella, Xerxes Malki, Deborah Oxley, Timothy Parsons, and Marco Sunder for valuable comments. I am very much indebted to Swati Mylavarapu, who arranged funding and coordinated field work in Kenya. Data collection was funded by the African Research Program at Harvard University, and their financial support is gratefully acknowledged. The usual disclaimer applies. 


\section{Introduction}

The colonial system stands for ruthless exploitation. By definition, it serves the interest of the metropolis, whereas the welfare of the indigenous population is of secondary importance in the target function of colonial rulers. A glance at prominent topics in the economic history of Kenya reveals that there is much in support of a pessimistic view. The British brought the region under their control in the last decade of the $19^{\text {th }}$ century. In the early 1900 s Africans were dispossessed of the best farming land and confined to 'native reserves'. Land was alienated to a tiny minority of European settlers, who subsequently gained strong political influence (Mosley, 1983; Wolff, 1974). In this labour scarce country, labour demands were met by means of force and through the imposition of hut and poll taxes, which required Africans to earn cash income and enter the wage economy (Clayton and Savage, 1974; Collier and Lal, 1986). Discriminatory regulations against African farmers were frequently put in place when settlers' interests were threatened. Africans were long prevented from cultivating most profitable export crops, in which the settlers had a stake, like coffee, tea, and pyrethrum and their products including maize, meat and hides were subject to price discrimination and hidden barriers imposed by monopsonistic marketing associations.

Certainly, without these policies welfare must have been higher. However, while it is fashionable to condemn colonial policies, there are certain changes that colonial times brought about which may have improved the lot of Kenyans, e.g. the introduction of a cash economy, modernization of infrastructure, expansion of trade, and the spread of Western medicine. Overall, the Kenyan economy grew, particularly commercial agriculture and the modern sector; using tax records Bigsten (1986) estimated that GDP per capita increased at an average annual rate of $3.1 \%$ between 
1914 and 1964. From independence in 1963 to 1980, in contrast, the economy grew by an average of $2.3 \%$ (Heston et al., 2002). Thus, the question remains: how well did Kenyans do under colonial rule? Were colonial times really as bad as commonly believed? How equal was the development between African groups?

This paper focuses on two important dimensions of living standards: nutrition and health. Existing accounts of nutrition come from studies of the Kikuyu, who constitute the largest ethnic group in Kenya, forming $20 \%$ of the population. Contemporary investigators painted a picture of widespread malnutrition and dietary deficiencies due to over-dependence on maize (Anderson, 1937; Orr and Gilks, 1931; Procter, 1926). Later researchers emphasised the role of colonial policies in generating land scarcity and actively promoting the decline of millet and beans in the diet which implies that nutritional deficits were a rather recent phenomenon (Brantley, 1997; MacKenzie, 1999; Taylor, 1970). ${ }^{1}$ This is surprising given the dearth of information on the pre-colonial period.

Medical reports leave no doubts that public health was in a poor state (Chaiken, 1998; Colony and Protectorate of Kenya, various years; Orr and Gilks, 1931). The impact on physical work capacity and labour productivity even attracted the concern of colonial authorities. The high incidence of infectious and parasitic diseases can be attributed to the harsh disease environment of tropical Africa. Nevertheless, there are voices like Dawson (1981), who point to new and 'unprecedented scales' of risks of contagion brought about by labour migration, urbanisation, and a rapid and lengthy

\footnotetext{
${ }^{1}$ That land alienation caused land scarcity and rural poverty is an argument that can be frequently found in the literature. From an economic point of view, this argument is flimsy. Land is a limited production factor - the area under cultivation cannot be extended indefinitely. Hence, even without land alienation, increases in per capita production need to come from a source other than opening the frontier.
} 
transport system. In fact, a comprehensive record of the outcome of investments in health infrastructure is missing.

Overall, existing studies are limited in population coverage (results presented in this paper suggest that the Kikuyu cannot be treated as representative). A particular problem is the diffuse nature of available data that does not lend itself to comparisons over time. Moreover, strong ideological biases exist. While older studies viewed matters from a Eurocentric perspective, newer studies of historians tend to stress the ills of colonial policies, regardless of the certainty of the factual impact. This study presents fresh evidence on the development of nutrition and health of various ethnic groups in colonial Kenya by (a) using a new and comprehensive data set of African army recruits and civilians, and (b) applying a powerful measure of nutritional and health status: average height of a population. For the very first time, precise comparisons can be made between the periods before colonisation and after independence. This study demonstrates that, however bad colonial policies were, nutrition and health steadily improved from the beginning of the $20^{\text {th }}$ century.

The paper is structured as follows. In the next section, a brief introduction is given to the measure of nutrition and health status. Section 3 presents the data. Section 4 clarifies the methodology and test strategy. In Section 5 follows an analysis of regional and social inequalities in early $20^{\text {th }}$ century Kenya. In section 6 , height data of cohorts born in pre-colonial and post-independence Kenya are added to derive a long-term series 1880-1980. The final section concludes.

\section{Nutritional Status, Body Stature, and Biological Standard of Living}


Anthropometry provides one of the best tools to assess nutritional and health status. There is a biological relationship between nutrition and health on the one hand and the physical development of children on the other. To the human body nutritional intake and body reserves provide energy which is absorbed by the maintenance of vital body functions (breathing, heart rate, etc.), diseases (raised body temperature, bodily wastes, parasites, etc.), physical activities and body growth (Srinivasan, 1992). The latter acts as a buffer, when intakes are low or energy expenditures are high. For the transformation of energy into body growth, certain micronutrients are also essential like iron, calcium, iodine or vitamin A. Accordingly, the body fails to grow at a normal rate as a result of chronically insufficient intakes - in terms of both quantity and quality - and a high burden of diseases and physical exertion. Mean height can be considered an indicator of a population's nutritional and health status.

Final adult height registers height increments cumulatively from foetal origins to maturity. ${ }^{2}$ However, not every phase of growth is equally important. A large share of total height is acquired in the first three years of life. ${ }^{3}$ It is also this period, when children are weaned, that they have quantitatively and qualitatively high energy needs and they are highly vulnerable to infections caused by unhygienic conditions or contaminated food (Martorell and Habicht, 1986). For this reason, deprived children typically fall behind in the early years of life and as shortfalls in growth can rarely be caught up later, much of the variation in adult height is set by age 4 (Dahlmann and Petersen, 1977).

The anthropometry based indicator has several advantages. Heights measure outcomes not inputs (Steckel, 1995). They do not, for example, discriminate against

\footnotetext{
${ }^{2}$ Growth retardation can already take place in utero (de Onis et al., 1998).

${ }^{3}$ Taking the NCHS reference population, healthy and well-nourished children would grow an average of $45 \mathrm{~cm}$ in the first three years of life, which represents $36 \%$ of the total gain from birth to maturity (Kuczmarski et al., 2002).
} 
certain foodstuffs; what matters is whether the diet is sufficient to meet the bodily needs of growing children; a mixture of leaves, groundnuts and beans, and a good grain staple can make up a suitable source of nutrients, even though animal products such as milk, meat, fish, and eggs often proved to be more effective. Furthermore, mean heights are responsive to distributional effects. Heights are subject to a decreasing marginal product. In other words, the height increment resulting from additional expenditures on nutrition and health will decrease with higher levels of consumption of nutrition and health inputs. Therefore, mean heights will decrease when redistributing inputs from the poor to the rich. Finally, it is not assumed that there is only one pattern of development. Height measurements are applicable to diverse social and economic systems that existed in Kenya including hunters, pastoralists, subsistence farmers, cash crop producers, employees in the modern and informal sector. This implies that mean height is a consistent measure over time. ${ }^{4}$

Kenya is home to more than 40 ethnic groups. What role does genetics play for heights? Genetics has indeed a strong influence on heights of individuals - it is expressed in the variance of individual heights that can be observed when individuals grew up under relatively equal conditions. However, when mean heights of populations are considered, the 'noise' of individual genetics cancels. Large height differences were found between rich and poor people of the same ethnic group, more so than between socio-economic elites of different ethnic backgrounds that grew up under good environmental conditions (Habicht et al., 1974; Martorell, 1984). Moreover, average heights vary considerably within the major ethno-linguistic groups in Kenya, the Bantu (Kamba, Kikuyu, Luhya, Meru, Mijikenda), Nilotic (Luo,

\footnotetext{
${ }^{4}$ The meaning of centimetre units can be comprehended from the close relationship to other indicators of well-being such as social status and income. Mean heights of $163 \mathrm{~cm}$ and $170 \mathrm{~cm}$, for example, are likely to be associated with per capita incomes in the order of 500 and 5000 US\$ respectively (Steckel, $1995)$. Similarly, the poor nutritional status of British army recruits born mid- $19^{\text {th }}$ century $(166 \mathrm{~cm})$ contrasts with Britain's working and upper class men nowadays $(176 \mathrm{~cm}$ and $178.2 \mathrm{~cm})$.
} 
Kalenjin, Samburu, Turkana, Maasai), and Cushitic (Somali), while there is a considerable overlap in the range. Plausible explanations other than genetics exist for the differences in stature (in fact, ethnicity is a marker of spatial, economic and social characteristics). Finally, the genetic pool of a population does not vary over short periods of time such as 10-50 years - mean height though does, if the environs have changed accordingly. By and large, environmental conditions are the determining factor of height differences between populations.

Heights must not be regarded narrowly as a measure of nutritional status. They have a much broader meaning. Children's body growth responds very sensitively to deprivation in essential human needs, i.e., when exposed to hunger, low-nutrient diets, poor housing and sanitary conditions, contaminated food and water, no or limited access to medical care, and child labour. Thus, average stature is a biological indicator of social and economic development and as such it is a component of the Biological Standard of Living (Komlos, 1989).

\section{Data Sources}

Historical sources of height measurements are diverse. Height was used for identification purposes and, as a measure of physical fitness, body stature was routinely taken in medical examinations, so that height data can be found for groups such as prison, hospital or school populations. Nutrition and health surveys frequently collected anthropometric data. Furthermore, anthropologists took a keen interest in the shape and body proportions of African ethnic groups. This study draws from these sources. The core data set, however, is derived from military records that have 
survived at the Defence Headquarters, Kenyan Armed Forces, Nairobi. Attestation papers and medical reports of 1,667 Kenyans enlisted in the British colonial forces provide details such as date of enlistment, regimental number, unit, place of birth, age, ethnicity, religion, the soldier's signature (if literate) and barefoot height.

Heights reveal the nutritional status of only those who were measured and findings can only be generalised to the extent to which the sample represents the broader population. Can a selection of army recruits be considered sufficiently representative of Kenyan men? Examining this issue, relevant facts about recruiting patterns are summarized in the following. In doing so, special reference is made to the data set.

In peace times, the British colonial army in Kenya was a small force. There was no conscription and the army was extremely selective, recruiting soldiers from ethnic groups with supposedly inherited military qualities, the so-called 'martial races' (Parsons, 1999: 54-103). In the 1920s and 1930s, martial races were pastoral and semi-pastoral groups from impoverished regions such as the Kamba, Kalenjin, and Somali. In contrast, Kikuyu and Meru of Central Kenya were hardly found in the army. World War II brought a massive expansion of military personnel. From an inter-war strength of less than 1,000 men the armed forces increased to 75,000 in 1943. Thus, every tenth adult man was serving in the military representing about $20 \%$ of the wage labour force (Parsons, 1999: 76). The huge demand for able-bodied and skilled men was met by extending the recruitment pool to communities the British did not considered martial. Additionally, the military offered wages above civilian levels. In 1941 , the pay ranged between 17 and 60 shillings per month for a newly trained private in the East African Military Labour Service (EAMLS) and East African Army Service Corps (EAASC) respectively, whereas civil wages for unskilled labour 
averaged between 8 and 12 shillings (Parsons, 1999: 73, 89). The military offered additional pulls such as uniforms, housing, food, professional training and promotion. Understandably, military service was popular (Parsons, 1999: 75).

It appears that WWII enlistees would provide a good coverage of ethnic and social backgrounds of Kenyan men. Therefore, this study focuses on WWII enlistees who comprise $85 \%$ of the data set. The WWII sub-sample indeed covers the larger ethnic groups in Kenya and the geographic origins of enlistees are widely spread (Figure 1). There are clusters of enlistees born in places around Lake Victoria and in the Highlands north of Nairobi. Fewer enlistees are from places in between or from the Northern parts of Kenya, but this is what one would expect from the lower population density of these areas (Trewartha, 1957). The only apparent drawback is that coastal peoples (Mijikenda, Pokomo, Taita, Taveta, and Swahili) are almost entirely missing. The ethnic composition of the sample of WWII enlistees deviates slightly from that of the Kenyan population (Table 1). The Kikuyu are somewhat underrepresented while Luo and Meru are overrepresented. However, since we are interested in differences between ethnic groups, their proportions are largely irrelevant. It is a much more crucial requirement that each ethnic group in the sample is sufficiently representative of each ethnic group in the population.

The East African Forces were a complex organisation with specialised branches and therefore, a high degree of differentiation can be found within the army. The most unskilled labour was pooled in labour units such as the EAMLS. The African Auxiliary Pioneer Corps (AAPC) took on somewhat more sophisticated works but it was still generally composed of men who did not meet the physical and intelligence requirements of combatant and technical units (Parsons, 1999: 85). The healthiest recruits were sent to frontline battalions of the King's African Rifles (KAR). 
Moreover, there were a number of support and specialist units that absorbed proficient and educated men such as the East African Army Service Corps (EAASC), which was responsible for motorised transport and logistics, the Signaller Corps, and the East African Army Medical Corps (EAAMC). The different requirements and qualifications were also reflected in pay scales. The data set, though it does not completely concur, covers some of the diversity within the East African Forces (Table 2). Most of the enlistees in the sample are from the EAMLS, which, however, does not count much, as their heights were seldom recorded. ${ }^{5}$ Next come the AAPC, EAAMC and KAR. The data set also contains a substantial number of about 100 enlistees of the EAASC and the Pack Transport Corps. These units account for $90 \%$ of the sample. Because they reflect the range of social and educational backgrounds of the men very well, membership to these units will be later used as explanation for height differences.

Despite the demand for recruits and the wide variety of employment opportunities, the army did not accept everyone. The most unfit men were certainly rejected on medical grounds. Official standards, which varied between units and changed over time, were also in place for age, height, weight, eyesight, and intelligence. Beyond the requirement of an age between 18 and 40, the most critical restriction is the minimum height requirement (MHR). Anderson (1943), a medical officer who served with the Forces, reported that stunted growth was a frequent cause of rejection. As short recruits were sorted out, available height measurements represent the taller men in the population. This is a potential source of bias. Fortunately, econometric techniques exist to overcome the problem. The procedure

\footnotetext{
${ }^{5}$ Height data is available for only 15 of the 385 men in the EAMLS. The Tanganyika Territory unit is the other case where height data is mostly missing. For all other units height measurements are available in more than $90 \%$ of the cases.
} 
will be explained in the next section. Furthermore, the data set does not include soldiers who were killed in action or died from accidents and disease. Because of the relatively low casualty rate of 3\% (Parsons, 1999: 35), biases from this source are likely to be negligible.

To conclude, the recruiting pattern of WWII makes enlistees an excellent sample that sufficiently represents the ethnic diversity and social backgrounds of a reasonably fit, male Kenyan wage labour force, aged 20-30 years.

Unfortunately, the sample of army recruits does not permit a thorough analysis of changes in height over a longer period of time. Therefore, a variety of other sources were consulted. Leys and Joyce (1913) provide an excellent coverage of ethnic groups for the pre-colonial time. They procured their measurements at the town surgery in Mombasa, from trivial cases. Additionally, they took measurements from villagers at a mission station, and political prisoners in Mombasa. Overall, Leys and Joyce (1913: 195) contend that their sample is 'fairly representative of the racial types' where height was considered a characteristic thereof. ${ }^{6}$ Furthermore, we make use of summary statistics of 1,271 physical examinations taken from 21-40 old men in the Kikuyu Reserve published in Orr and Gilks (1931: 77). For post-independence Kenya, anthropometric data was retrieved from the nationally representative Kenya Demographic and Health Survey 2003 (Macro). The DHS survey provides data for women but not for men. Female heights are therefore transformed into male equivalents, an approach described in more detail in the next section.

\footnotetext{
${ }^{6}$ Leys and Joyce (1913) also drew measurements from policemen and applicants for admission to the police force, who 'were certainly above the tribal average in physique'. The remark probably refers to the Indians, Somalis, Comorians, and Swahilis in their sample who predominated amongst the rank and file at that time (Foran, 1962: 23). As Leys and Joyce (1913) published the measurement of each individual, it was possible to screen the height distributions for abnormal behaviours. Some distributions were slightly positively skewed. A truncated regression with truncation points at 62 and 64 inches did not produce significantly different results. When re-estimating the means, a major error of half an inch in the case of the Luo ethnic group was found. The digitised data is available from the author and at http://www.economics.ox.ac.uk/Members/alexander.moradi/data.html.
} 


\section{Methodology}

Heights are most informative about conditions of nutrition and health in the first few years after birth. Many WWII enlistees did not know their year of birth or their age. In these cases, their age was either estimated, described as "adult" or the entry was simply left blank. Using the available age data gives an average age at enlistment of 26.5 years. About $70 \%$ of the enlistees were aged 20-35. Hence, most WWII enlistees were born in the 1910-1920 period (Figure 2). The heights, therefore, refer to conditions during this period.

The army required recruits to pass a minimum height and short stature was indeed a frequent cause of rejection (Anderson, 1943). The shortfall of recruits at the lower tail of the height distribution is a severe problem; without proper treatment, mean height estimates will be upwardly biased. Anthropometric historians were frequently confronted with deficient height distributions. From various techniques that were proposed to overcome the problem, truncated normal regression became the method of choice (A'Hearn, 2004; Heintel, 1996; Komlos, 2004).

Truncated normal regression is a standard technique in econometrics (Greene, 2008). From an underlying data generating process of the form

$$
y_{i}=\beta^{\prime} x_{i}+\varepsilon_{i} \quad \text { where } \quad \varepsilon_{i} \sim N\left(0, \sigma^{2}\right)
$$

the sample is restricted to those cases, where $y$ is greater than the truncation point $\tau$ (in the left truncated situation). From assuming normality in the underlying process it follows that $y$ has a truncated normal distribution in the sample data. Its density can be expressed as 


$$
\mathrm{f}\left(\mathrm{y}_{i}\right)=\frac{\frac{1}{\sigma} \phi\left(\left(y_{i}-\beta^{\prime} x_{i}\right) / \sigma\right)}{1-\Phi\left[\left(\tau-\beta^{\prime} x_{i}\right) / \sigma\right]}
$$

where $\phi($.$) and \Phi(\cdot)$ denote the standard normal pdf and cdf respectively. The maximum likelihood estimator (MLE) chooses the parameters $\beta$ and $\sigma$ that maximise the sum of $\operatorname{logs}$ of these densities. ${ }^{7}$ Truncated MLE is an unbiased, consistent and asymptotically efficient estimator of $\beta$. Normality is a crucial assumption, which, however, reasonably holds for heights in homogeneous populations. In this study, we use an unconstrained MLE, where no ad-hoc restrictions on the standard deviation $\sigma$ of the underlying population are made.

To apply this technique, knowledge of $\tau$ is needed. ${ }^{8}$ According to Medical Handbooks, the pre-war MHR was 5'7' (Parsons, 1999: 85). In the course of the huge demand in WWII, physical requirements were officially lowered to 5'3" except for the EAMLS which was lowered to 5 '2" in 1942. The Signals had no height requirement and recruits as young as 15 years were accepted (Owino, 2004). The recruits in the data set mostly enrolled between 1939 and 1941, where requirements may have been in transition. Moreover, there were a couple of exceptions and recruiters did not always pay attention to the guidelines. In order to determine the de facto truncation point, histograms are examined (Komlos, 2004). Taking WWII enlistees as a whole the histogram indicates a shortfall starting at 66 inches and growing at 64 inches (lower right panel, Figure 3). When distinguishing by branch,

\footnotetext{
${ }^{7}$ Details of the estimation procedure are described in Greene (2008). A'Hearn (2004) and Komlos (2004) provide specific references to the case of heights.

${ }^{8}$ The truncation point $\tau$ corresponds to the minimum height requirement. Even though one can observe recruits with heights below the MHR, the probability is firstly, lower than in a true random sample and secondly, of unknown extent. By truncating all observations below $\tau$, probabilities can be derived via the normality assumption.
} 
various truncation points can be observed (Figure 3). ${ }^{9}$ In particular, truncation points could be identified at 63 (EAAMC, General Hospital), 65 (PT Corps and Camel Transport, EAASC), and 66 (AAPC and KAR) inches. For the small number of recruits in the Signals no MHR is assumed. ${ }^{10}$ Note that MHRs are well below the sample modes, a feature which enhances the reliability of the estimates.

Using the sample of African army recruits, the following regression models will be estimated. The start will make a specification, in which ethnic group is taken as the single predictor of mean height. Ethnicity is a fundamental clue to geographical origin (Figure 1). Taking ethnicity as regional entity also facilitates comparisons with other data sources (Kenyan administrative units changed frequently). Next, the effect of social and educational background on nutritional status will be tested. In particular, the recruit's ability to sign the attestation paper and the membership to the branches are used as proxy variables. Finally, for taking into account that environmental influences changed over time, variables are used that indicate the year of birth (in the case of the WWII army sample, birth years are restricted to the $1900-1920$ period). In all three models, dummy variables for ages 15-22 years are included in order to control for lower statures of individuals who have not attained their final adult height at the time of measurement.

For post-independence Kenya, height data of women are used. It is possible to predict male heights from female heights based on prevalent patterns of sexual dimorphism in stature (Baten, 2007). Admittedly, nutritional status of the genders does not perfectly correlate. Aspects of dimorphism in stature are influenced by gender-specific differences in environments including discriminatory resource

\footnotetext{
${ }^{9}$ Height maxima do not seem to be a concern here.

${ }^{10}$ Results are robust to slight variations in the choice of truncation points. I experimented with a MHR of 67 inches for KAR and AAPC as well as a one inch higher truncation point for all branches.
} 
allocation between girls and boys. The approach can nevertheless be justified on the grounds that the relationship is strong and that prediction errors are typically small. ${ }^{11}$ Differences or changes in gender dimorphism are therefore unlikely to delude conclusions about secular trend in the heights of Kenyan ethnic groups. Female heights were transformed into male equivalents assuming a male to female ratio of $106.77 \%$ found in the sample of African populations of Gustafsson and Lindenfors (2004). ${ }^{12}$ This is a rather conservative estimate.

A potential caveat for the long-term series $1880-1980$ is that it is compiled from four cross-sections. Thus, there is a risk that the observed height differences reflect differences in the backgrounds of the sampled population rather than genuine changes over time. However, from what is known of the backgrounds one would not expect major biases.

\section{Regional inequality: A cross section of WWII enlistees}

Mean stature estimates of WWII enlistees indicate a pronounced regional inequality in nutritional and health status (Table 3, column 1). With an average height of 65.1 inches $(165.4 \mathrm{~cm})$ the agricultural Kikuyu and Meru of the Central Highlands were the shortest. Spatially, this region is the nadir from which stature gradually

\footnotetext{
${ }^{11}$ To be clear on this, excess dimorphism in stature of two centimetres is by no means trivial (Moradi and Guntupalli, forthcoming). Boys and girls living in the same household are subject to many similar environmental conditions. Gender dimorphism in stature can therefore be expected to be much smaller than height differences over space, time or between social classes.

${ }^{12} \mathrm{Sub}$-Saharan Africa was found to be a region with a relatively favourable nutritional status of women as compared to men (Klasen, 1996; Svedberg, 1990). Based on a sample of 58 Negroid populations Eveleth (1975) estimated the relationship: "Male Height=-1.81+1.078*Female Height". When using the sample of sub-Saharan African populations published in Gustafsson and Lindenfors (2004) and excluding the pygmies who make up a disproportionate share of their sample, I arrive at "Male Height $=-0.85+1.073 *$ Female Height", $\mathrm{R}^{2}=0.96$. Note that the constant is not significantly different from zero, so that one can simplify and assume a ratio of male to female heights in the order of $106.77 \%$.
} 
increases. Semi-pastoralist groups like the Kamba in the east and the Kalenjin in the west were 66.1 and 66.3 inches $(167.9 \mathrm{~cm}$ and $168.4 \mathrm{~cm})$ respectively while the various pastoralist groups and Somalis in the Northern arid area attained a mean height of 66.9 inches $(170 \mathrm{~cm})$. Interestingly, with an average height of 67.7 inches $(171.9 \mathrm{~cm})$ Luos and Kisii, summarized as "Others", living at the shores of Lake Victoria were the tallest.

The height differences between ethnic groups should not be interpreted as the result of colonial policies or short term influences. Without doubt, shocks and crises do affect heights. However, they usually do not change the life of communities dramatically and sustainedly. Therefore, a large proportion in cross-sectional height differences may rather reflect longer-term or structural causes. What factors can explain the observed height differences?

The harsh epidemiological environment is an obvious factor to start with. Prevalent diseases include diarrhoea, pneumonia and other respiratory illnesses, diphtheria, measles, malaria, yellow fever, sleeping sickness, dengue, plague, smallpox, schistosomiasis and other parasites like hookworms. The repeated episodes of infectious diseases or constant exposures in particular play a major role in hindering the nutrient absorption, limiting catch-up growth, and therewith, putting a strain on the body growth of the surviving child population. However, while I strongly believe that the disease environment limited the height potential in general, the available evidence for health as the driving factor behind the spatial pattern in Kenyan heights is ambiguous.

Pronounced regional differences in exposure to diseases are difficult to establish. The malaria vector and parasite, for example, is constrained by temperature, humidity, and the existence of bodies of water (Craig et al., 1999). Accordingly, 
malaria was endemic around Lake Victoria and in the Central Highlands. The arid areas in the North were prone to epidemics after rainfalls. Only the Western Highlands, where most of the European farmers settled, were malaria-free. Differences in the epidemiological environment may be expected to arise from differences in population density, because crowding facilitates the accumulation and transmission of bacteria, viruses and parasites. On this account, nomadic life could have been associated with better health, which agrees with the tall stature of pastoralists. ${ }^{13}$ In contrast, the densely populated areas of the Central Highlands and Lake Victoria should have the worst epidemiological environment. These are the settlement areas respectively of the Kikuyu and Luo who, however, can be found on the opposite sides of the height scale.

An investigation of 16 villages in 1922 in the area north of Lake Victoria showed an infant mortality rate in the range between 335 and 514 per 1,000 live births and an average rate of 424 (Colony and Protectorate of Kenya, 1923: 21). Interestingly, one could observe a spatial pattern, in that infant mortality tended to decrease with distance to the Lake. Stature, however, does not follow this pattern: Luhya and Kalenjin were shorter than the Luo.

Nutrition is much more in line with the observed height differences. Following Roudledge and Roudledge (1910), Leakey (1977), Procter (1926) and others, Orr and Gilks (1931: 21) described the Kikuyu as agriculturalists who lived on an essentially vegetarian diet consisting of cereals (maize and millet), tubers, plantains, legumes, and green leaves. Though Kikuyus had goats and sheep, they were used as currency. Meat was primarily consumed on occasions of sacrifices or festivals and it was confined to the elders. Probably more importantly, little milk was available. Milk is

\footnotetext{
${ }^{13}$ Prince and Steckel (2003) argued on similar lines to explain the tall stature of American Indians in the $19^{\text {th }}$ century.
} 
believed to play a crucial role in the development of infants and children (Baten and Murray, 2000; Takahashi, 1984). Easily digestible by infants and young children, milk contains large amounts of proteins, minerals and vitamins that are important inputs for muscle and bone formation. Orr and Gilks (1931: 9) concluded that the Kikuyu diet was high in carbohydrates and low in protein, vitamin A, iron and calcium. Even though no detailed quantitative account exists, these general observations could well explain the 'poor physique' of Kikuyu WWII enlistees. ${ }^{14}$

Nutrition also provides a plausible explanation for the remarkable stature of the Luos at the shores of Lake Victoria. Their livelihood centred around fishing, farming and livestock herding (Geheb and Binns, 1997). The soils were mostly of good quality, so that yields were presumably high. Because of surpluses in agricultural production, Fearn (1961: 80) regarded this region as the 'granary of East Africa'. Fish provided another rich source of protein. Additionally, the tri-economy represents a good portfolio to distribute risks against rainfall shocks.

It is not surprising that Kenyan pastoralists had a tall stature. The livestock they reared was a source of high quality proteins, particularly milk and meat. The herds of cattle, sheep, and goats represented a considerable buying power that could be used to supplement their diet with produce from farmers. Clearly, when taking livestock as wealth and currency, pastoralists were one of the richest groups in Kenya.

\footnotetext{
${ }^{14}$ Recently, Brantley (1997) dismissed the Orr and Gilks study as 'colonial science'. She particularly criticised the portrayal of a 'discrete tribal diet' and their omission that malnutrition and poverty came as a result of colonialism. In contrast, she considered the Kikuyu diet to be rich and very effective, so that the Kikuyu had the 'luxury of avoidance' [of meat] (Brantley, 1997: 65). Though I agree that there is variation beyond averages and that the two cases, where it was possible to have the food weighed for the meals of one day, may be a thin basis for Gilks and Orr's calculations of dietary intakes, indications of a rich and varied diet are not persuasive. One can easily imagine that descriptions about the variety of foodstuffs give a wrong impression of their significance in daily diets. Arriving at ideologically predetermined conclusions, her study essentially reveals an insufficient understanding of biological processes and an erroneous perception of pre-colonial times. This becomes clear from height trends presented in the next section.
} 
Heights of WWII enlistees also exhibit traces of social inequality. The few who were literate on enlistment $(7 \%)$ were probably of higher social background, as parents could afford to invest in education and forego the labour that their children could contribute to the household. Literacy was indeed associated with a better nutritional status, though not significantly so (Table 3, column 2). In section 3 , it was argued that membership of certain military branches can also be taken as proxy for abilities. Controlling for ethnicity, there are indeed significant differences. Enlistees of the KAR, the unit which took the most able-bodied men, were 0.7 inches taller than members of the AAPC, EAMLS or Camel Transport Corps who serve here as the reference category. Similarly, medical personnel enrolled in EAAMC and General Hospital were 0.6 inches taller. Men in the Pack Transport Corps, who were probably the least skilled manual labourers, were 2.5 inches shorter. Contrary to expectations, Signals were 1.1 inches shorter than the reference group. This is probably an age effect; educated personnel were in such a short supply that the army specifically recruited teenagers at ages $15-18$ to the Signals; if the majority of recruits in the Signals had not attained their final height, they are naturally shorter than their adult comrades. $^{15}$

In the final regression, birth cohort effects were tested, i.e. changes in nutritional status over time (Table 3, column 3). The sample size is considerably reduced, because only those cases where the age is known enter the regression. Moreover, it might be possible that selection effects were a function of age, e.g. one might suspect that enlistees older than 30 years were accepted because of special skills. As it is not possible to control for these confounding factors, the results need to

\footnotetext{
${ }^{15}$ The lowest recorded age of a Signals was 27 years. It therefore can be assumed that the age of teenagers was not recorded (if teenagers were the rule rather than the exception for this unit), and the age effect is not taken up by the age dummies in the regression.
} 
be treated with care. Nevertheless, it is worth mentioning that a significant trend in stature of cohorts born in the 1900s and 1910s cannot be found.

\section{Pre-colonial and post-independence Kenya}

Birth cohorts that cover the pre-colonial and post-independence period complete the insights into changes in nutritional status over time. From the compiled series several features stand out (Figure 4). Firstly, there are only small height differences between 1880 and 1910 birth cohorts. Mean heights of Luo and Luhya did not change at all, while the one of the Kikuyu and Kamba increased. Secondly, mean height of all ethnic groups except for the Kamba increased in the $20^{\text {th }}$ century. Improvements in nutritional status started during colonial times and continued at almost the same pace after Kenyan independence in 1963. Mean height of Kikuyu men increased by an astonishing $0.7 \mathrm{~cm}$ per decade; Kalenjin and Luhya grew by about $0.5 \mathrm{~cm}$ per decade and Luo men by $0.3 \mathrm{~cm}$ per decade. As increments were larger the shorter the initial stature, one is inclined to see an indication for convergence, if it had not been for the experience of the Kamba. It nevertheless follows, thirdly, that differences in nutritional status between ethnic groups declined. The 7.5 centimetre height difference between the tallest and the shortest ethnic group in cohorts born around 1880 has decreased to 5.6 centimetres in 1980 birth cohorts.

At this point, some qualifications are in order. First of all, the development of

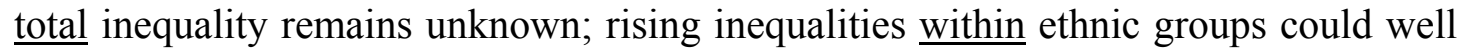
have offset the decreasing inequality between ethnic groups. Qualitative reports as well as Gini coefficients of tax income suggest indeed that inequality increased, 
brought about by Kuznets like income differentials between economic sectors and rising inequality among smallholders (Bigsten, 1986; Kitching, 1980). Moreover, it is clear that a secular trend derived from three points in time omits important short-term fluctuations. Kenya has a history of crises. In the 1890s, for example, Kenyans were hit by a series of natural calamities. Rinderpest swept through the country causing cattle losses of 80-90 per cent (Mack, 1970); locust swarms and a lengthy drought added to this resulting in a devastating famine in $1897-1899 .{ }^{16}$ Other crises include WWI, the influenza epidemic in 1918, economic slumps during the early 1920s and the Great Depression, and food shortages in $1943 .{ }^{17}$ Similarly, one would expect negative consequences from the loss of land, hut and poll taxes, coercive labour, discriminatory policies against African producers, the change in staple food from beans and millet to less nutritious white maize, etc. we cannot say much about the impact of short-term crises or the impact of specific events or policies. However, what can be concluded is that inspite of whatever detrimental impacts they had, nutritional status improved in the long run.

A comparison with other countries supports the optimistic view of Kenya's colonial development. In industrialised countries mean heights grew at a faster pace than in Kenya (Table 4). In the US, the rate was one centimetre per decade; in Britain it was somewhat lower. Certainly, it would have been surprising if Kenya outperformed the metropole. Developing countries hardly ever achieved such rates, but some did, as the example of Colombia shows. However, Kenya compared well to most other developing countries like Mexico. Colonies in South and South East Asia performed more poorly. India, for example, stagnated at very low levels. What has

\footnotetext{
${ }^{16}$ In fact, droughts and locust swarms occur frequently in Eastern Africa and are not sufficient to cause outbreak of famines.

${ }^{17}$ Adult height is less imprinted by short-term crises than one might expect. If, after a famine, for example, conditions get quickly back to normal, the surviving child population may quickly recover and catch up in height.
} 
caused the secular trend in Kenya? Several potential determinants can be put forward. As their influences are difficult to quantify, explanations offered here are tentative.

The beneficial effects of Western medicine on health and living standards in Kenya are frequently overlooked. From the 1920s onwards the health infrastructure expanded considerably. While 130,000 Kenyans were treated in 'native hospitals' in 1920, the number of patients increased to 500,000 in 1936 and to one million in 1948 (Colony and Protectorate of Kenya, 1923; 1937; 1949). Additional 110,000, 620,000 and 1.4 million attendances were counted in out-dispensaries in 1923, 1936 and 1948 respectively. By no means did the colonial system provide universal access, given the 1948 Census population of 5.2 million. Nevertheless, the rate of growth is extremely impressive.

Specific health strategies changed over the years. In the 1920s, for example, a campaign targeted tropical yaws, which was very common in rural areas. More than 700,000 Africans were treated and the incidence of the disease dropped markedly (Dawson, 1987; Wilkinson, 1957). Despite large-scale interventions like this, the colonial medical system placed an emphasis on preventive rather than curative care. Efforts included improvements in sanitation, health education, and vector management, specifically, large-scale extermination of rats and bush clearances (Chaiken, 1998). In the early years, immunisations targeted plague and smallpox; later vaccines, addressed tuberculosis and polio. Then, in the 1950s, modern antibiotics, particularly penicillin, became available, making treatments more effective overall.

The decentralized pattern of service delivery helped to extend medical coverage significantly. Several towns had hospitals and clinics; out-dispensaries, staffed with skilled African personnel, served rural areas and members of the medical department regularly undertook 'medical safaris' to remote communities. Geographically, 
medical services were indeed astonishingly well-distributed (Figure 5). Nairobi had a favoured position compared to other regions in terms of hospitals: in 1948, for example, $20 \%$ of hospital patients were treated in Nairobi whereas her population share represented only $2 \%$. On the other side of the scale is the Lake region (Nyanza), where only $6 \%$ of all hospital patients were treated despite a population share of $34 \%$. However, taking patients at out-dispensaries into account, provision of health care was roughly balanced $-21 \%$ and $8 \%$ for Nyanza and Nairobi respectively. In addition, health care was financed by local taxes so that most services were provided without charging fees to Africans (Chaiken, 1998: 1715).

The spread of Western medicine had an impact on mortality. Rough estimates of infant mortality rates in 'native areas' in the 1920s ranged between 300 and 500 deaths per 1,000 live births (Gilks and Orr, 1927: 561), whereas infant mortality rates of 147.1 and 91.5 are reported for the $1950-55$ and $1970-75$ period respectively (UN Population Division, 2007). Brass and Jolly (1993: 27) confirmed the downward trend in death rates of children aged 0-5 years; applying indirect methods to Kenyan Census data they arrived at a child mortality rate of 270 for 1940 decreasing to 153 in 1974 .

Summing up, progress in health care was substantial in the 1920-1970 period. The improvements in health almost certainly contributed to the positive trend in the nutritional status of Africans. However, the different experiences of ethnic groups suggest that health cannot be considered the only cause. The remarkable increase in stature of the Kikuyu is particularly striking and it is not clear why the Kikuyu should have benefited disproportionately from health services.

Improvements in nutrition must also be taken into account. Most Kenyans were dependant on agriculture for their livelihood - approximately $90 \%$ of the population in 1950 (FAOSTAT). Hence, the agricultural sector is of substantial importance. 
Unfortunately, quantitative aspects of agricultural production and trade are fuzzy. The output in subsistence agriculture is not observed. Moreover, African production found its way to domestic consumers mostly through informal marketing channels organised by African producers and traders, and Indian traders (Kitching, 1980). It is only from the 1930s onwards that economic surveys and trade statistics provide a rough indication.

From the beginning of the century, a predominantly subsistence-based economy slowly changed to one based on commodity exchange. In the 1920s, the commercialisation of agriculture gained momentum (Van Zwanenberg, 1974). The portfolio of cash-crops included wattle bark, sim sim, cotton, meat, and hides. Maize cultivation in particular, grown for the domestic market, expanded rapidly benefiting both, African producers and consumers. Shifting cultivation and long fallow periods made way to more intensive production. Both the area under cultivation and agricultural production increased.

Development was not uniform across regions. Using per capita sales of agricultural produce outside the district as a measure of peasant prosperity, Mosley (1982: 400) found that Kikuyu and Luo/Luhya districts were on equal footing in 1929: sales of about three shillings were recorded for both regions. In 1945, however, the corresponding figures were five and 17 shillings (in 1929 prices) indicating that Kikuyu peasants were more prosperous. The different paths continued after WWII. A land reform programme in 1954 aimed at consolidating fragmented lands and providing for freehold titles (Swynnerton, 1954, 1962). Restrictions on coffee cultivation were weakened. The so-called Swynnerton plan brought additional incentives to intensification and cash crop production. Productivity increased and cash revenues of African smallholders tripled during 1955-64 (Kitching, 1980; Leys, 
1975). The reform had the greatest impact in the Highlands north of Nairobi, where the Kikuyu settled.

The Kamba reserve had very different ecological and economic conditions and reports predominantly point to agronomic deterioration from the 1930s onwards: soil erosion from overgrazing and intensive farming practices, low productivity and underproduction, etc. (Rocheleau et al., 1995). The Kamba lived on marginal lands susceptible to shortfalls in rain. From the early 1940s to the late 1950s, the Kamba reserve experienced a series of droughts (Munro, 1975: 192). The Kamba repeatedly suffered from food shortages that could not be fully mitigated by migrant wage labour.

Certainly, there are other factors to consider beyond agricultural production. Increasing inequality, for example, put downward pressure on mean heights and one may indeed speculate whether this affected Kikuyu heights as a whole. Other factors also include child care practices, education, real wages, proximity to markets and infrastructure. Ultimately, increasing heights reflected prosperity in a broad sense, whereas the different height trajectories of ethnic groups mirrored the economic inequalities at that time.

\section{Summary}

Kenya was a settler economy and as such, colonial policies were exploitative and discriminatory, more so than in other African colonies. The existing economic and social history literature is characterised by a pessimistic view of the colonial period pointing to immiseration and downplaying aspects of modernisation. The 
factual account, however, is essentially uncertain. Data is lacking and unreliable, and most measures fail to take into account differing economic systems and the transformation that took place in Kenya. Anthropometric indicators do not suffer from these shortcomings. Mean height of a population measures the outcome of nutrition and health consistently, and hence, indicates how well basic human needs are met.

Using height data from African army recruits and civilians this study found evidence for the following. Firstly, large regional inequalities existed in late $19^{\text {th }}$ and early $20^{\text {th }}$ century Kenya. Nutritional status was exceptionally poor in the central region, whereas conditions around Lake Victoria and in pastoral zones were much more favourable. Secondly, the nutritional status of cohorts born in the 20 years prior and after colonisation did not change significantly. Therefore, accounts of precolonial sufficiency, often implicitly made, cannot be maintained. Thirdly, from 1920 onwards secular improvements took place which continued after independence over the first 15 years of independence. Fourthly, this development was particularly dynamic in the central region, so that inequality between ethnic groups declined over the course of the $20^{\text {th }}$ century.

It was hypothesised that climate-related diseases limited the height potential of ethnic groups indiscriminately and that the expanding health infrastructure, slightly favouring the central region and urban areas, improved the nutritional and health status of most Kenyans. It was argued that nutrition is the factor that can explain the spatial pattern as well as the differences in mean height trajectories of ethnic groups; nutritional status essentially followed economic prosperity.

This study is the very first which has analysed the Biological Standard of Living in an Eastern African colony. It is necessarily limited. The current data set cannot account for the ups and downs in the $20^{\text {th }}$ century. Short term crises are 
important as their occurrences indicate failure to reduce exposure to risks. Also, it cannot be said much about inequality within ethnic groups. The increasing differentiation within the Kikuyu is a predominant topic and indeed important for understanding the Mau Mau uprising in the 1950s. Clearly, more research is needed. The potential of anthropometric techniques is not exhausted by this study. Historical records of body stature are an untapped source in African economic history. Heights of other social and occupational groups that allow for longer series and more covariates, would be of great value in confirming the trends and providing a detailed account of social inequalities.

Acknowledging these limitations, one finding nonetheless stands out: colonial times were not as bad as commonly believed. In fact, Kenya colony outperformed places like Mexico or India. By no means would I argue that colonialism was good. Colonial policies were a long way from maximising the welfare of the indigenous population, and not all of the changes that occurred during the colonial era were the result of intention. One could imagine that the same gains could have been achieved without the colonial impetus. In other words, a proper counterfactual must rather evaluate what could have been achieved without British governance. The postindependence period can serve as a valid comparison group. However, one must be prepared to find that improvements during the latter do not stand up to the ones during the colonial era, particularly when the post-1980s years were considered. 
Figure 1 Ethnic group and place of birth/origin of Kenyan WWII enlistees

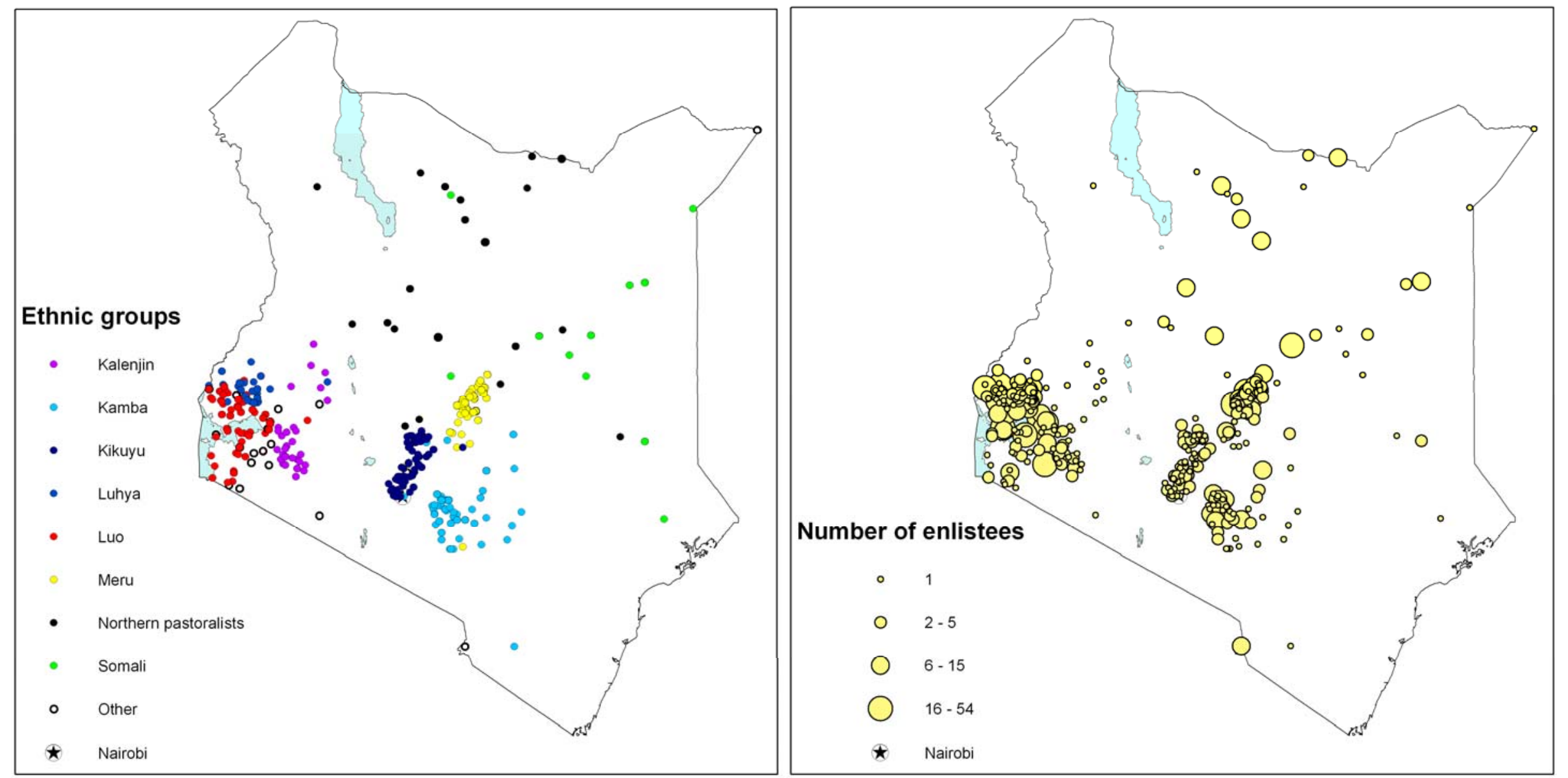

Note: Places of birth/origin were derived from attestation papers of Kenyan WW2 enlistees. The places were matched with entries in the Geographic Names Database of the National Geospatial-Intelligence Agency, from which latitude and longitude were retrieved. The database is the official repository of foreign place name decisions approved by the U.S. Board on Geographic Names (National Geospatial-Intelligence Agency, 2007). It was possible to locate 89\% of WW2 enlistees from my sample of 1,439. 
Figure 2 Year of birth and year of enlistment

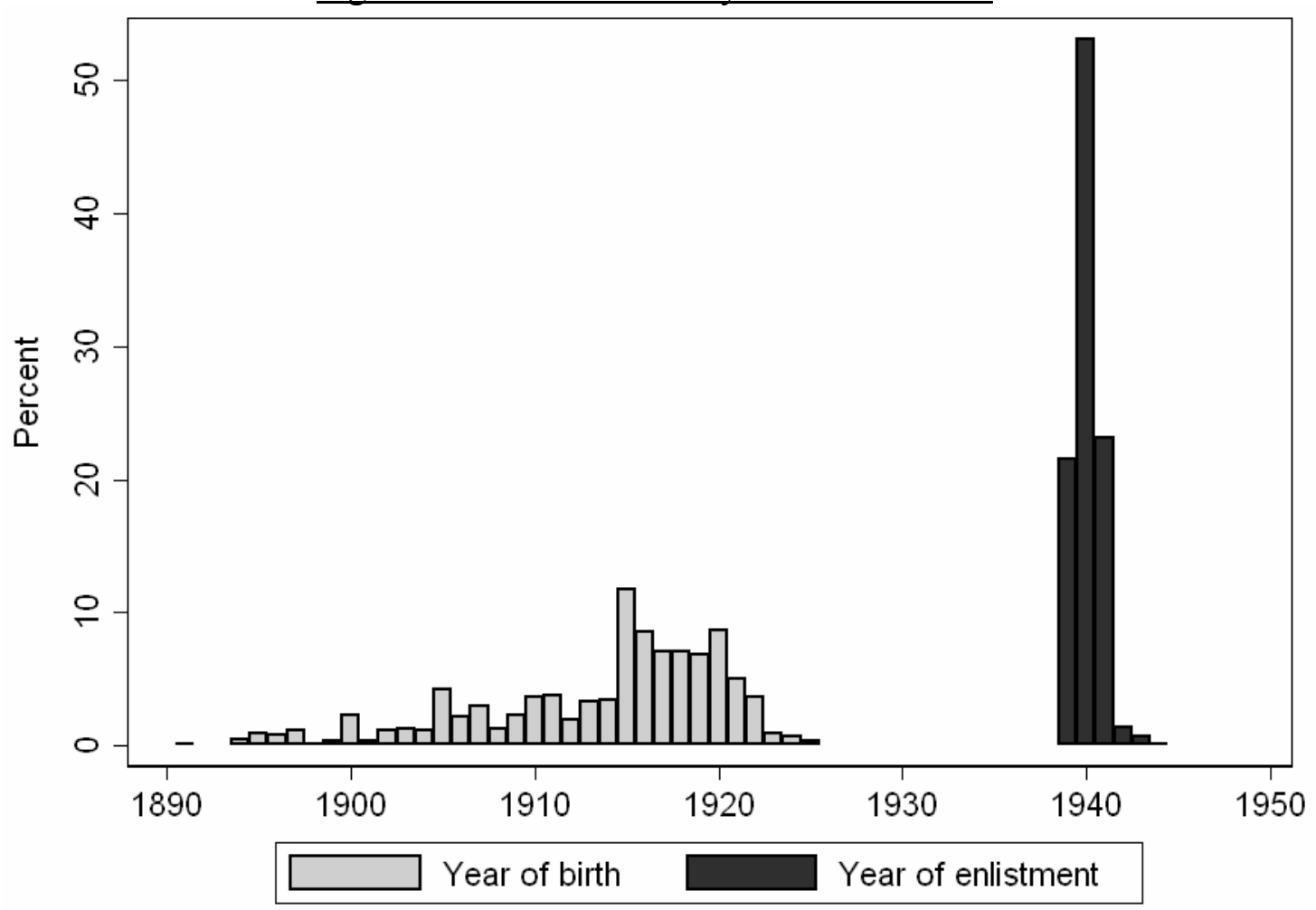

Note: The age was only recorded for a fraction of enlistees. N(year of birth/ year of enlistment): 610/ 1439. Mean age of enlistees was 26.5 years.

Figure 3 Height distributions by branch of service
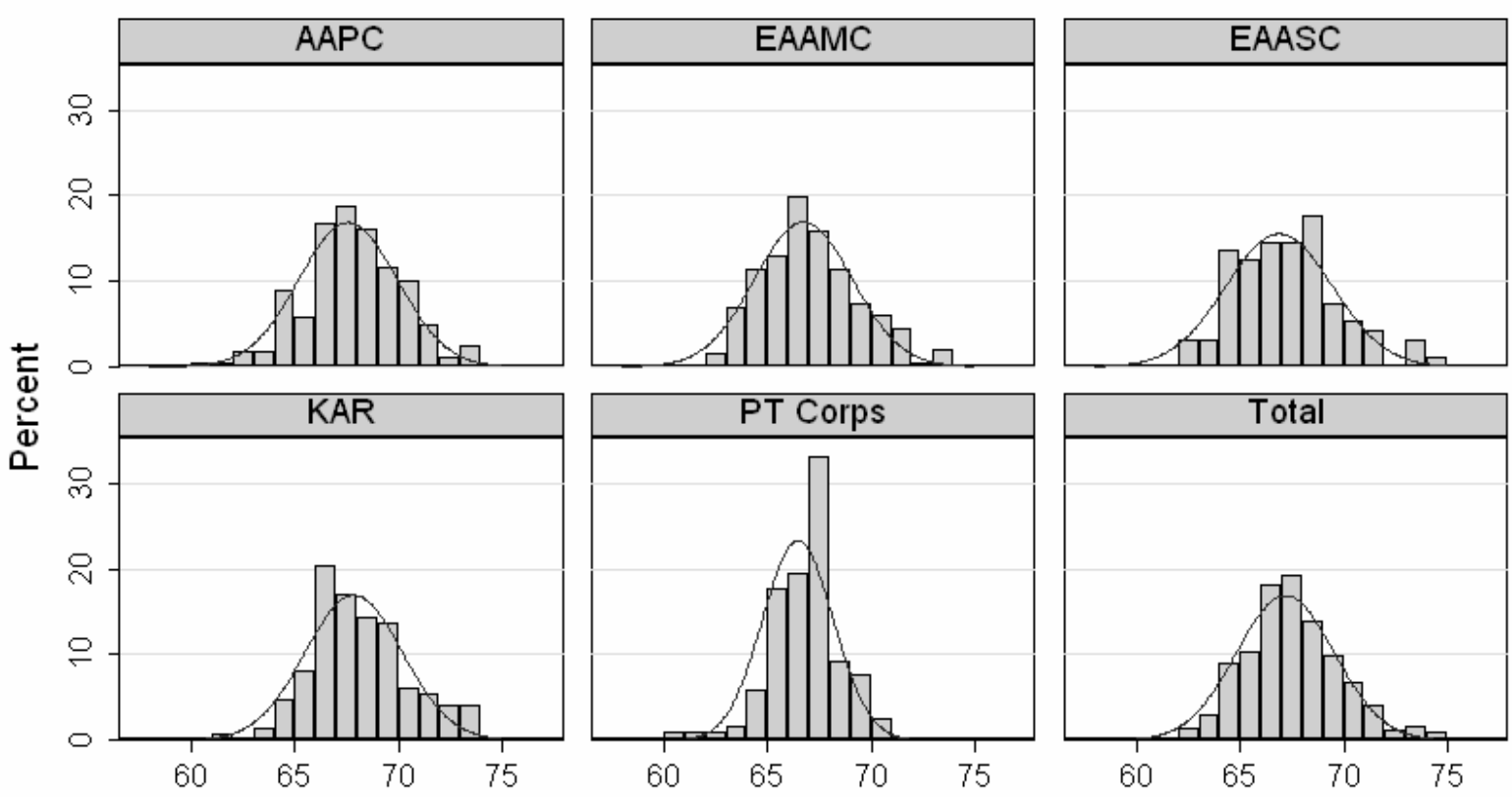

Height (in inches)

\section{observed distribution}

\section{normal distribution}

Note: Bin width is one inch. Truncation point chosen is 63 inches for EAAMC, 65 inches for PT Corps and EAASC, and 66 inches for AAPC and KAR. About $22 \%$ of the available height measurements fall below the truncation point. 
Figure 4 Mean heights in Kenya, pooled cross sections 1880-1980

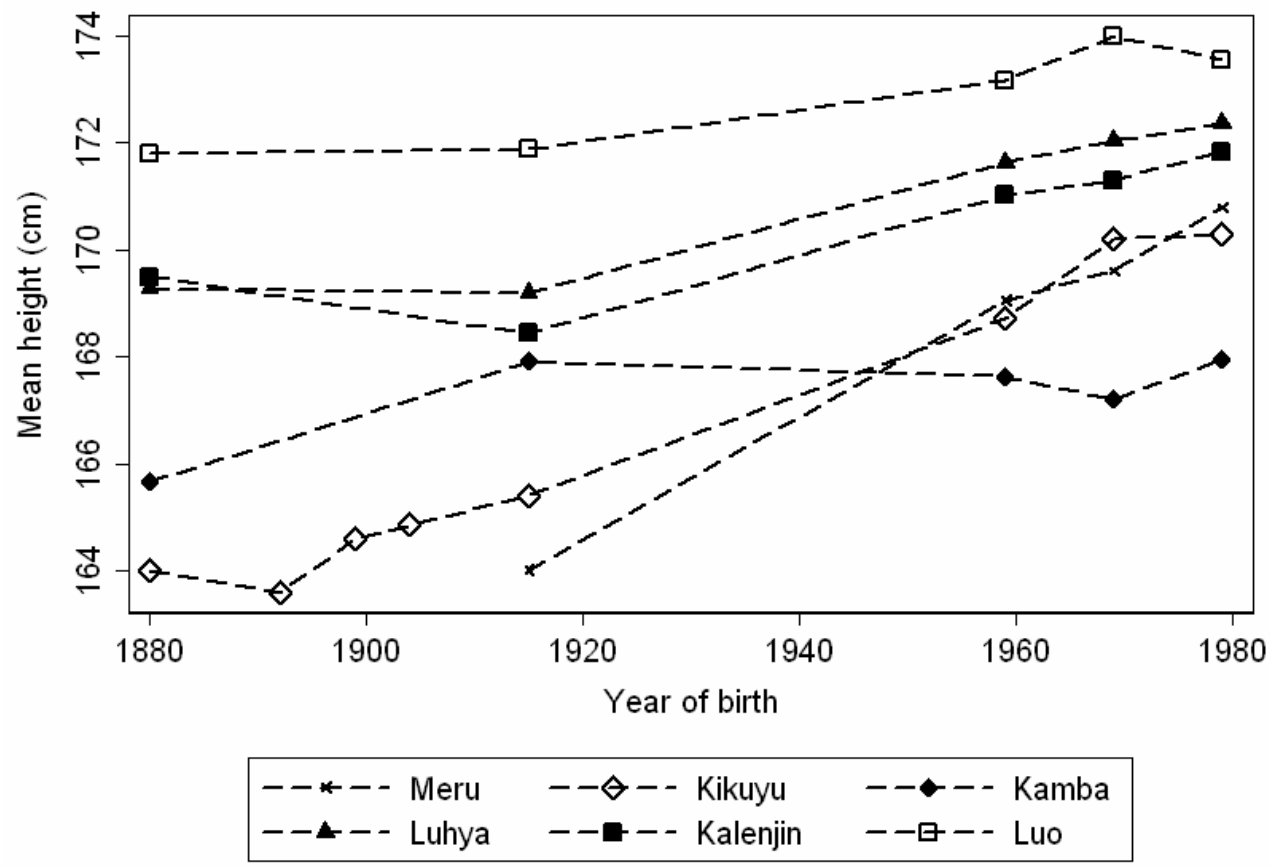

Note: Heights of the earliest birth cohorts were taken from Leys and Joyce (1913: 207). I replaced obsolete ethnic categories. In particular, 'Bantu Kavirondo' were taken as Luhya, while 'Nandi', 'Suk' and 'Kamasia' were summarised as Kalenjin (Olson, 1996). In these cases, the mean height represents a weighted average. Leys and Joyce (1913: 195) report to have measured 'adult males' only. In absence of any further particulars, I arrived at an approximate calculation of 1880 as the year of birth $(\mathrm{N}=622)$. Orr and Gilks (1931: 77) provide the three data points for the Kikuyu in 1892, 1899 and 1904 (age groups: 31-40, 26-30, 21-25; N=1271). Birth cohorts of the 1910s are based on Kenyan WWII enlistees as discussed in section 3. The heights were derived from the estimate in regression (1), Table 3 . The latest birth cohorts are male equivalents derived from heights of women surveyed in the Kenya DHS 2003 (see footnote $12 ; \mathrm{N}=4319)$.

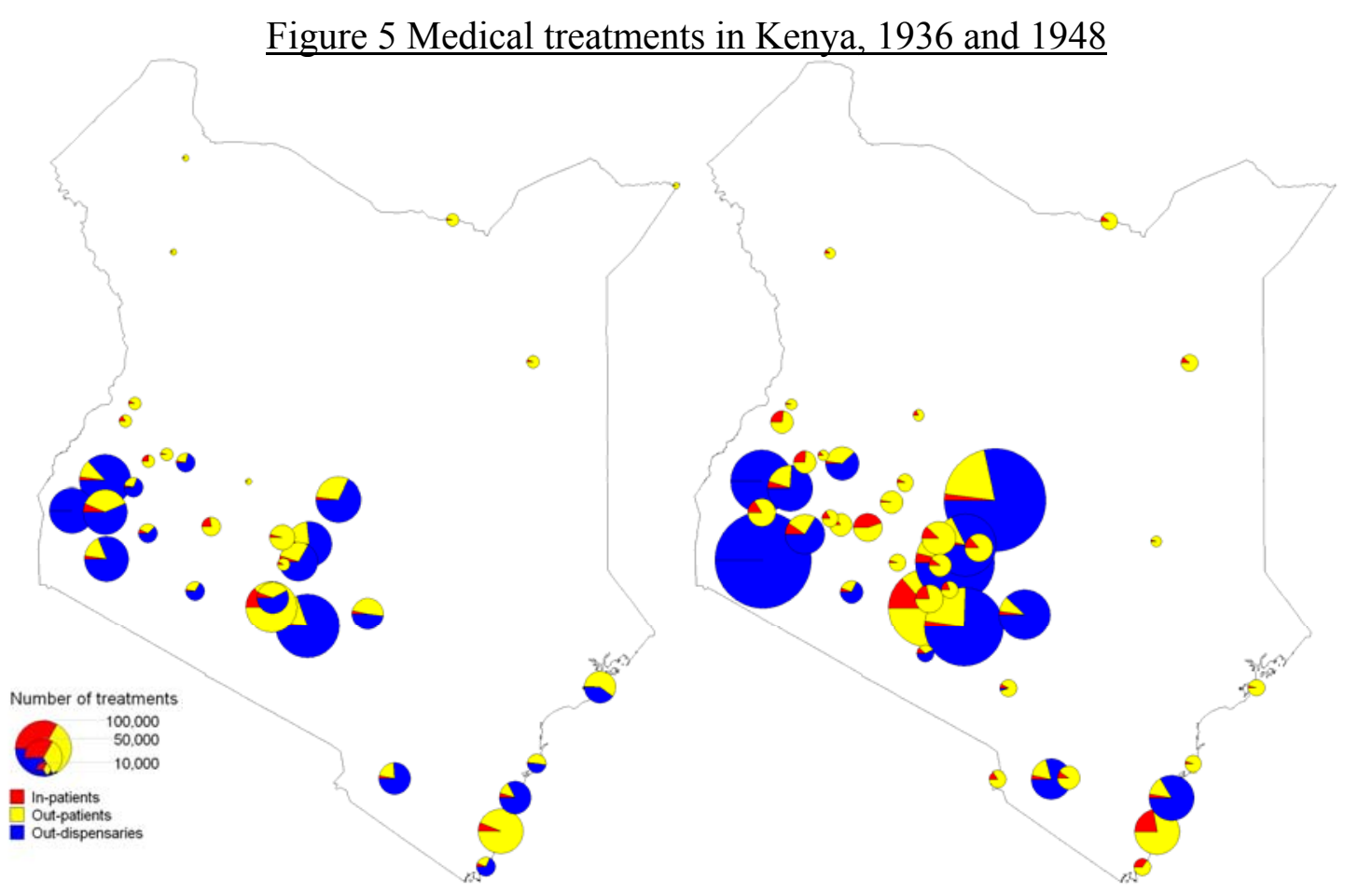

Source: Colony and Protectorate of Kenya (1937; 1949) 
Table 1: Ethnic groups in the sample of WWII enlistees and the Kenyan population (in \%)

\begin{tabular}{lccc}
\hline \hline Ethnic group & $\begin{array}{c}\text { Sample of WWII } \\
\text { enlistees }\end{array}$ & Census 1948 & Census 1962 \\
\hline Kikuyu & 8.9 & 19.5 & 19.1 \\
Luo & 30.3 & 13.3 & 13.3 \\
Luhya & 7.9 & 12.5 & 12.6 \\
Kamba & 9.7 & 11.6 & 10.8 \\
Kalenjin & 3.6 & 6.5 & 10.4 \\
Kisii & 2.5 & 4.9 & 6.3 \\
Meru & 23.8 & 6.2 & 5.1 \\
Mijikenda & 0.0 & 4.6 & 4.8 \\
Somali and other & 9.1 & 1.5 & 6.8 \\
Northern Pastoralists & 4.1 & 19.4 & 10.6 \\
Other & & &
\end{tabular}

Note: Number of WWII enlistees in the data set is 1,431. The Census figures are from East African Statistical Department (1950: 5) and Kenya Ministry of Finance and Economic Planning (1964) respectively. The latter is more reliable.

Table 2: Descriptives of Military Units, WWII

\begin{tabular}{lcccc}
\hline \hline & Sample of WWII enlistees & $\begin{array}{c}\text { East African } \\
\text { Forces } \\
\text { April } 1942\end{array}$ & $\begin{array}{c}\text { Monthly pay } \\
\text { of a private } \\
1940-41\end{array}$ \\
Unit & N & Percentage & Percentage & Shillings \\
\hline East African Military Labour Service & 385 & 26.9 & 12.3 & 17 \\
African Auxiliary Pioneer Corps & 297 & 20.7 & 13.6 & 46 \\
East African Army Medical Corps & 206 & 14.4 & 6.0 & 28 \\
King's African Rifles & 161 & 11.2 & 14.3 & $60^{\#}$ \\
Pack Transport Corps & 123 & 8.6 & & 28 \\
East African Army Service Corps & 96 & 6.7 & 32.8 & \\
Tanganyika Territory & 54 & 3.8 & & \\
Force HQ Signals & 32 & 2.2 & 3.1 & \\
Other & 78 & 5.5 & 18.0 & \\
Total & 1432 & 100.0 & 100.0 & \\
\hline \hline
\end{tabular}

Note: The breakdown of the East African forces in 1942 and the military pay rates are from Parsons (1999: 72, 89). ${ }^{\#}$ This pay probably refers to a driver in the EAASC. 
Table 3: Determinants of height: Unconstrained ML Estimates

\begin{tabular}{|c|c|c|c|c|}
\hline & Mean & (1) & (2) & (3) \\
\hline Constant & & $\begin{array}{l}65.119^{* * *} \\
(156.66)\end{array}$ & $\begin{array}{l}65.112^{* * *} \\
(105.75)\end{array}$ & $\begin{array}{c}64.695^{* * *} \\
(73.53)\end{array}$ \\
\hline \multicolumn{5}{|l|}{ Ethnic groups } \\
\hline Kikuyu & 0.123 & $\begin{array}{l}\text { Reference } \\
\text { group }\end{array}$ & $\begin{array}{l}\text { Reference } \\
\text { group }\end{array}$ & $\begin{array}{l}\text { Reference } \\
\text { group }\end{array}$ \\
\hline Meru & 0.015 & $\begin{array}{l}-0.550 \\
(-0.61)\end{array}$ & $\begin{array}{l}0.211 \\
(0.22)\end{array}$ & \\
\hline Kalenjin & 0.035 & $\begin{array}{l}1.195^{*} \\
(1.72)\end{array}$ & $\begin{array}{l}1.571^{*} \\
(1.94)\end{array}$ & $\begin{array}{l}1.593^{*} \\
(1.74)\end{array}$ \\
\hline Kamba & 0.110 & $\begin{array}{c}0.984^{*} \\
(1.93)\end{array}$ & $\begin{array}{l}1.391 * * * \\
(2.77)\end{array}$ & $\begin{array}{l}1.660^{*} \\
(1.87)\end{array}$ \\
\hline Luhya & 0.118 & $\begin{array}{l}1.492 * * * \\
(3.07)\end{array}$ & $\begin{array}{c}1.455 * * * \\
(3.19)\end{array}$ & $\begin{array}{c}1.956^{* *} \\
(2.34)\end{array}$ \\
\hline Somali/ Northern pastoralists & 0.130 & $\begin{array}{c}1.790 * * * \\
(3.37)\end{array}$ & $\begin{array}{l}3.484 * * * \\
(3.92)\end{array}$ & $\begin{array}{l}3.014 * * * \\
(3.55)\end{array}$ \\
\hline Luo & 0.389 & $\begin{array}{l}2.551 * * * \\
(6.09)\end{array}$ & $\begin{array}{l}2.405 * * * \\
(5.24)\end{array}$ & $\begin{array}{c}2.554 * * * \\
(3.50)\end{array}$ \\
\hline Other & 0.080 & $\begin{array}{l}2.773 * * * \\
(4.01)\end{array}$ & $\begin{array}{l}2.864 * * * \\
(3.62)\end{array}$ & $\begin{array}{l}3.370^{* * *} \\
(3.13)\end{array}$ \\
\hline \multicolumn{5}{|l|}{ Birth cohort } \\
\hline 1900-1909 & 0.252 & & & $\begin{array}{l}\text { Reference } \\
\text { group }\end{array}$ \\
\hline $1910-1915$ & 0.206 & & & $\begin{array}{l}-0.253 \\
(-0.43)\end{array}$ \\
\hline $1915-1919$ & 0.541 & & & $\begin{array}{l}0.452 \\
(0.84)\end{array}$ \\
\hline \multicolumn{5}{|l|}{ Branches of Service } \\
\hline $\begin{array}{l}\text { AAPC \& EAMLS \& Camel } \\
\text { Transport Corps }\end{array}$ & 0.328 & & $\begin{array}{l}\text { Reference } \\
\text { group }\end{array}$ & \\
\hline PT Corps & 0.118 & & $\begin{array}{c}-2.525 * * * \\
(-3.33)\end{array}$ & \\
\hline EAAMC \& General Hospital & 0.289 & & $\begin{array}{l}0.554 \\
(1.23)\end{array}$ & \\
\hline EAASC & 0.088 & & $\begin{array}{l}-0.429 \\
(-0.66)\end{array}$ & \\
\hline KAR & 0.140 & & $\begin{array}{l}0.684 \\
(1.61)\end{array}$ & \\
\hline Signals & 0.038 & & $\begin{array}{l}-1.097 * \\
(-1.63)\end{array}$ & \\
\hline $\begin{array}{l}\text { Literate } \\
\text { (Signature on attestation paper) }\end{array}$ & 0.071 & & $\begin{array}{l}0.403 \\
(0.72)\end{array}$ & \\
\hline
\end{tabular}


Age fixed effects for ages 15 to 22 years

(if age is known) [p-value]

$$
[0.06]^{*} \quad[0.03]^{* *} \quad[0.90]
$$

$\begin{array}{lll}2.68 & 2.56 & 2.63\end{array}$

$738 \quad 730 \quad 325$

\begin{tabular}{|c|c|c|c|}
\hline Sigma & 2.68 & 2.56 & 2.63 \\
\hline $\mathrm{N}$ & 738 & 730 & 325 \\
\hline
\end{tabular}

Table 4: International comparison: Mean adult height of men

\begin{tabular}{lcccccc}
\hline \hline Birth cohort & Britain & US & Colombia & Mexico & India & Kenya \\
\hline 1880 & & 169.5 & & 163.9 & & 167.7 \\
1890 & & 169.1 & & 163.9 & & \\
1900 & & 170.0 & & 163.9 & & \\
1910 & & 172.1 & 162.8 & 163.7 & 163.3 & 168.0 \\
1920 & & 173.1 & 163.9 & 163.5 & 163.7 & \\
1930 & 173.6 & 173.4 & 164.9 & 165.5 & 163.9 & \\
1940 & 174.1 & 176.1 & 166.0 & 165.8 & 163.9 & \\
1950 & 175.1 & 177.1 & 167.5 & & & 170.3 \\
1960 & 176.0 & 177.3 & 168.3 & & & 170.9 \\
1970 & & 177.5 & 169.0 & & & 1.2 \\
1980 & & & & & \\
\hline \hline
\end{tabular}

Sources:

Britain: (Rosenbaum et al., 1985: 117)

US: (Costa and Steckel, 1997: 72)

Colombia: (Meisel and Vega, 2007: 108)

Mexico: (Lopez-Alonso and Condey, 2003)

India: (Guntupalli and Baten, 2006: 591-2)

Kenya: Calculation is based on the ethnic groups in my analysis (see notes below Figure 4), which were weighted by their population share in 1962 . 


\section{$\underline{\text { References }}$}

A'Hearn, B. (2004). A Restricted Maximum Likelihood Estimator for Truncated Height Samples. Economics \& Human Biology 2(1): 5-19.

Anderson, T. F. (1937). Kikuyu Diet. East African Medical Journal 14: 120-131.

Anderson, T. F. (1943). The Diet of the African Soldier. East African Medical Journal 20(7): 207-213.

Baten, J. (2007). Global Height Trends in Industrial and Developing Countries, 1810-1984: An Overview. Mimeo, University of Tuebingen.

Baten, J. and J. E. Murray (2000). Heights of Men and Women in 19th Century Bavaria : Economic, Nutritional, and Disease Influences. Explorations in Economic History 37(4): 351-369.

Bigsten, A. (1986). Welfare and Economic Growth in Kenya, 1914-76. World Development 14(9): $1151-1160$.

Brantley, C. (1997). Kikuyu-Maasai Nutrition and Colonial Science : The Orr and Gilks Study in Late 1920s Kenya Revisited. The International Journal of African Historical Studies 30(1): 49-86.

Brass, W. and C. L. Jolly (1993). Population Dynamics of Kenya. Washington, D.C: National Academy Press.

Chaiken, M. S. (1998). Primary Health Care Initiatives in Colonial Kenya. World Development 26(9): 1701-1717.

Clayton, A. and D. C. Savage (1974). Government and Labour in Kenya, 1895-1963. London: Cass.

Collier, P. and D. Lal (1986). Labour and Poverty in Kenya 1900-1980. Oxford: Clarendon Press.

Colony and Protectorate of Kenya (1923). Annual Medical Report for the Year Ending 31st December 1922. Nairobi.

Costa, D. L. and R. H. Steckel (1997). Long Term Trends in Health, Welfare and Economic Growth in the United States. Health and Welfare During Industrialization. R. H. Steckel and R. Floud. Chicago: University of Chicago Press: 47-89.

Craig, M. H., R. W. Snow and D. Le Sueur (1999). A Climate Based Distribution Model of Malaria Transmission in Sub-Saharan Africa. Parasitology Today 15(3): 105-111.

Dahlmann, N. and K. Petersen (1977). Influences of Environmental Conditions During Infancy on Final Body Stature. Pediatric Research 11(5): 695-700.

Dawson, M. H. (1981). Disease and Population Decline of the Kikuyu of Kenya, 1890-1925. African Historical Demography, Volume Ii; Proceedings of a Seminar Held in the Centre of African Studies, University of Edinburgh, 24th and 25th April 1981. C. Fyfe and D. N. McMaster. Edinburgh: Centre of African Studies, University of Edinburgh, : 121-138.

Dawson, M. H. (1987). The 1920s Anti-Yaws Campaigns and Colonial Medical Policy in Kenya. International Journal of African Historical Studies 20(3): 417-435.

de Onis, M., M. Blossner and J. Villar (1998). Levels and Patterns of Intrauterine Growth Retardation in Developing Countries. European Journal of Clinical Nutrition 52(1): S5-S15.

East African Statistical Department (1950). African Population of Kenya Colony and Protectorate : Geographical and Tribal Studies : East African Population Census, 1948. Nairobi: East African Statistical Department. 
Eveleth, P. B. (1975). Differences between Ethnic Groups in Sex Dimorphism in Adult Height. Annals of Human Biology 2(1): 35-39.

FAOSTAT. FAO Statistical Data Bases. from http://faostat.fao.org/.

Fearn, H. (1961). An African Economy : A Study of the Economic Development of the Nyanza Province of Kenya, 1903-1953. Oxford University Press: London.

Foran, W. R. (1962). The Kenya Police: 1887-1960. London: Robert Hale.

Geheb, K. and T. Binns (1997). 'Fishing Farmers' or 'Farming Fishermen'? The Quest for Household Income and Nutritional Security on the Kenyan Shores of Lake Victoria. African Affairs 96(382): 73-93.

Gilks, J. L. and J. B. Orr (1927). The Nutritional Condition of the East African Native. Lancet 209(5402): 560-562.

Greene, W. H. (2008). Econometric Analysis. Upper Saddle River, N.J.: Pearson/Prentice Hall.

Guntupalli, A. M. and J. Baten (2006). The Development and Inequality of Heights in North, West and East India 1915-44. Explorations in Economic History 43(4): 578-608.

Gustafsson, A. and P. Lindenfors (2004). Human Size Evolution: No Evolutionary Allometric Relationship between Male and Female Stature. Journal of Human Evolution 47(4): 253-266.

Habicht, J.-P., C. Yarbrough, R. Martorell, R. M. Malina and R. E. Klein (1974). Height and Weight Standards for Preschool Children : How Relevant Are Ethnic Differences? Lancet 303 (7858): 611-615.

Heintel, M. (1996). Historical Height Samples with Shortfall: A Computational Approach. History and Computing 8: 24-37.

Heston, A., R. Summers and B. Aten (2002). Penn World Table Version 6.1, Center for International Comparisons at the University of Pennsylvania (CICUP).

Kenya Ministry of Finance and Economic Planning (1964). Kenya Population Census, 1962: Nairobi.

Kitching, G. N. (1980). Class and Economic Change in Kenya : The Making of an African Petite Bourgeoisie 1905-1970. New Haven ; London: Yale University Press.

Klasen, S. (1996). Nutrition, Health, and Mortality in Sub Saharan Africa: Is There a Gender Bias? Journal of Development Studies 32(6): 913-932.

Komlos, J. (1989). Nutrition and Economic Development in the Eighteenth-Century Habsburg Monarchy : An Anthropometric History. Princeton: Princeton University Press.

Komlos, J. (2004). How to (and How Not to) Analyze Deficient Height Samples: An Introduction. Historical Methods 37(4): 160-173.

Kuczmarski, R. J., C. L. Ogden, S. S. Guo, L. M. Grummer-Strawn, K. M. Flegal, Z. Mei, R. Wie, L. R. Curtin, A. F. Roche and C. L. Johnson (2002). 2000 CDC Growth Charts for the United States : Methods and Development. Vital and Health Statistics 11(246): 1-190.

Leakey, L. S. B. (1977). The Southern Kikuyu before 1903. London: Academic Press.

Leys, C. (1975). Underdevelopment in Kenya : The Political Economy of Neo-Colonialism, 1964-1971. Berkeley: University of California Press.

Leys, N. M. and T. A. Joyce (1913). Note on a Series of Physical Measurements from East Africa. Journal of the Royal Anthropological Institute of Great Britain and Ireland 43(1): 195-267. 
Lopez-Alonso, M. and R. P. Condey (2003). The Ups and Downs of Mexican Economic Growth : The Biological Standard of Living and Inequality, 1870-1950. Economics \& Human Biology 1(2): 169.

Mack, R. (1970). The Great African Cattle Plague Epidemic of the 1890's. Tropical Animal Health and Production 2(4): 210-219.

MacKenzie, A. F. D. (1999). Betterment and the Gendered Politics of Maize Production, Murang'a District, Central Province, Kenya, 1880-1952. Canadian Journal of African Studies 33(1): 6497.

Macro. Demographic and Health Surveys. Retrieved March, 2006, from http://www.measuredhs.com.

Martorell, R. (1984). Genetics, Environment, and Growth : Issues in the Assessment of Nutritional Status. Genetic Factors in Nutrition. A. Velazques and H. Bourges. New York: Academic Press: 373-392.

Martorell, R. and J.-P. Habicht (1986). Growth in Early Childhood in Developing Countries. Human Growth : A Comprehensive Treatise. F. Falkner and J. M. Tanner. New York: Plenum. 3: 241262.

Meisel, A. and M. Vega (2007). The Biological Standard of Living (and Its Convergence) in Colombia, 1870-2003: A Tropical Success Story. Economics \& Human Biology 5(1): 100-122.

Moradi, A. and A. M. Guntupalli (forthcoming). What Does Gender Dimorphism in Stature Tell Us About Discrimination in Rural India, 1930-1975? Gender Bias: Health, Nutrition and Work. M. Pal, P. Bharati, B. Ghosh and T. S. Vasulu. New Dehli: Oxford University Press.

Mosley, P. (1982). Agricultural Development and Government Policy in Settler Economies: The Case of Kenya and Southern Rhodesia, 1900-60. Economic History Review 35(3): 390-408.

Mosley, P. (1983). The Settler Economies: Studies in the Economic History of Kenya and Southern Rhodesia 1900-1963. Cambridge: Cambridge University Press.

Munro, J. F. (1975). Colonial Rule and the Kamba : Social Change in the Kenya Highlands, 18891939. Oxford: Clarendon Press.

National Geospatial-Intelligence Agency (2007). NGA Geonet Names Server, http://gnswww.nga.mil/geonames/GNS/index.jsp.

Olson, J. S. (1996). The Peoples of Africa : An Ethnohistorical Dictionary. Westport, Conn. ; London: Greenwood Press.

Orr, J. B. and J. L. Gilks (1931). Studies of Nutrition : The Physique and Health of Two African Tribes. London Medical Research Council, Special Report Series No. 155.

Owino, M. (2004). Military Service and the Health of African Troops in Colonial Kenya. Fall 2004 SERSAS Conference. North Carolina.

Parsons, T. H. (1999). The African Rank-and-File : Social Implications of Colonial Military Service in the King's African Rifles, 1902-1964. Portsmouth, NH ; Oxford: Heinemann.

Prince, J. M. and R. H. Steckel (2003). Nutritional Success on the Great Plains : Nineteenth Century Equestrian Nomads. Journal of Interdisciplinary History 33(3): 353-384.

Procter, R. A. W. (1926). The Kikuyu Market and Kikuyu Diet. Kenya Medical Journal 3: 15-22.

Rocheleau, D. E., P. E. Steinberg and P. A. Benjamin (1995). Environment, Development, Crisis, and Crusade: Ukambani, Kenya, 1890-1990. World Development 23(6): 1037-1051. 
Rosenbaum, S., R. K. Skinner, I. B. Knight and J. S. Garrow (1985). A Survey of Heights and Weights of Adults in Great Britain, 1980. Annals of Human Biology 12(2): 115-127.

Routledge, W. S. and K. Routledge (1910). With a Prehistoric People, the Akikuyu of British East Africa. London: Edward Arnold.

Srinivasan, T. N. (1992). Undernutrition : Concepts, Measurement and Policy Implications. Nutrition and Poverty. S. R. Osmani. Oxford: Oxford University Press: 97-120.

Steckel, R. H. (1995). Stature and the Standard of Living. Journal of Economic Literature 33(4): 1903 1940.

Svedberg, P. (1990). Undernutrition in Sub-Saharan Africa: Is There a Gender Bias? Journal of Development Studies 26(3): 469-486.

Swynnerton, R. J. M. (1954). A Plan to Intensify the Development of African Agriculture in Kenya. Nairobi: Colony and Protectorate of Kenya.

Swynnerton, R. J. M. (1962). Agricultural Advances in Eastern Africa. African Affairs 61(244): 201 215.

Takahashi, E. (1984). Secular Trend in Milk Consumption and Growth in Japan. Human Biology 56(3): 427-437.

Taylor, D. R. F. (1970). Changing Food Habits in Kikuyuland. Canadian Journal of African Studies 4(3): 333-349.

Trewartha, G. T. (1957). New Population Maps of Uganda, Kenya, Nyasaland, and Gold Coast. Annals of the Association of American Geographers 47(1): 42-58.

UN Population Division (2007). World Population Prospects: The 2006 Revision.

Van Zwanenberg, R. (1974). The Development of Peasant Commodity Production in Kenya, 1920-40. Economic History Review 27(3): 442-454.

Wilkinson, J. (1957). The Origin of Infectious Disease in East Africa, with Special Reference to the Kikuyu People. East African Medical Journal 34(10): 545-553.

Wolff, R. D. (1974). The Economics of Colonialism : Britain and Kenya, 1870-1930. New Haven ; London: Yale University Press. 